\title{
MPOROROITE, A NEW SECONDARY TUNGSTEN MINERAL FROM UGANDA
}

\author{
Oleg v. Knorring, Th. G. Sahama \\ and Martiti Lehtinen
}

\begin{abstract}
v. Knorring, Oleg, Sahama, Th. G. and Lehtinen, Martit 1972: Mpororoite, a new secondary tungsten mineral from Uganda. Bull. Geol. Soc. Finland 44, 107-110.
\end{abstract}

A secondary tungsten mineral was found from the scheelite-bearing ferberite deposit of Mpororo in south-western Uganda, and named after the locality. The mineral occurs as greenish-yellow powdery masses. Based on electron diffraction data, the X-ray powder pattern was indexed and the unit cell parameters were calculated. The mineral is monoclinic or nearly so with $a_{0}=8.27$ $\AA, b_{0}=9.32 \AA, c_{0}=16.40 \AA, \beta=92^{\circ} 29^{\prime}, V=1263 \AA^{3}$. The composition, determined by wet chemical analysis, corresponds to the simplified formula (Al, $\mathrm{Fe})_{2} \mathrm{O}_{3} \cdot 2 \mathrm{WO}_{3} \cdot 6 \mathrm{H}_{2} \mathrm{O}$ with $Z=5$. This composition of mpororoite differs from that of anthoinite in that it has almost one half of the amount of aluminum replaced by iron and contains roughly twice as much water. A combined DTA and TGA run indicates that, on heating, the amount of water is expelled in three distinct steps, the first two of which (below $90^{\circ} \mathrm{C}$ and $90-$ $145^{\circ} \mathrm{C}$, respectively) most probably represent loss of water molecules of the structure. The habits of anthoinite and mpororoite, as revealed by electron microscopy, are closely similar to each other.

Oleg v. Knorring, Dept. of Earth Sciences, Leeds University, U. K.

Th. G. Sabama and Martti Lebtinen, Dept. of Geology, University of Helsinki, 00170 Helsinki 17, Finland.

The Mpororo tungsten deposit (approx. E $\left.29^{\circ} 41^{\prime} 52^{\prime \prime}-\mathrm{S} 1^{\circ} 5^{\prime} 46^{\prime \prime}\right)$ is situated in the south-western part of the Impenetrable Forest Area, some $20 \mathrm{~km}$ north of the town of Kisoro in the Kigezi District, Uganda. Wolfram was discovered in the area in 1931 in the gravels of the Kibisamwika-Rusho and Mpororo streams, the former being a tributary of the Kabale river. The tungsten mineralization at Mpororo is similar to that of other occurrences in the Kigezi District and adjoining parts of Rwanda and the Congo. It is most probably confined to a specific horizon of graphitic phyllites which are intensely folded and intruded by swarms of quartz veins. The veins which are frequently concordant with the bedding have apparently mobilized, absorbed and redeposited the primary tungsten of the graphitic phyllites. The major mineral of these deposits is 
ferberite, which often replaces scheelite, either in the form of pseudomorphs after scheelite or more frequently forms cavernous box- or honeycombstructures of ferberite. The scheelite is rarely preserved and the cavities between the ferberite septae of the boxes are now empty or filled with secondary alteration products, such as anthoinite, ferritungstite (or its aluminum analogue) and cerotungstite.

According to Combe (1939), the tungstenbearing quartz veins at Mpororo are associated with dark-blue to black graphitic phyllites which are characterized by the presence of abundant cubical cavities after pyrite, limonite pseudomorphs after pyrite and sometimes fresh pyrite cubes. The quartz veins range from mere stringers to veins as much as $1 \frac{1}{2} \mathrm{~m}$ wide. The contact of the quartz and phyllite is always sharp and without micaceous selvage. Mpororo is unique amoung the ferberite occurrences in the area because it contains a large amount of scheelite at all stages of replacement in addition to the ferberite of different habit. Pyrite is a common associate of the scheelite mineralization. Moreover the scheelite is altered to a greenishyellow powdery mineral with a distinct structure and composition, the subject of the present paper.

Roe (1943), who first observed the scheelite at Mpororo, compared the tungsten mineralization with that of the Sintok Mine in northern Kedah, Malaysia, near the border of Thailand.

The secondary tungsten mineral found at Mpororo can not be distinguished from anthoinite in a hand specimen. The grain size is too small for optical microscopy. Viewed under the electron microscope, the mineral displays a platy habit closely similar to that of anthoirite. The electron diffraction pattern and the X-ray powder pattern are specific of the mineral and differ from the patterns exhibited by anthoinite. The mineral represents a distinct species named mpororoite in this paper, after the locality. This name has been approved by the Commission on New Minerals and Mineral Names of the International Mineralogical Association.
TABLe 1.

X-ray powder pattern of mpororoite.

\begin{tabular}{|c|c|c|c|c|}
\hline $\mathrm{hkl}$ & & $d_{\text {meas }}$ & $d_{\text {calc }}$ & $I$ \\
\hline 002 & $\ldots \ldots \ldots$ & 8.21 & 8.19 & 100 \\
\hline 110 & $\ldots \ldots \ldots$ & 6.18 & 6.18 & 16 \\
\hline 102 & $\ldots \ldots \ldots$ & 5.69 & 5.70 & 18 \\
\hline 013 & $\ldots \ldots \ldots$ & 4.73 & 4.71 & 13 \\
\hline $11 \overline{3}$ & $\ldots \ldots \ldots$ & 4.20 & 4.16 & 17 \\
\hline 004 & $\ldots \ldots \ldots$ & 4.09 & 4.10 & 19 \\
\hline 210 & $\ldots \ldots \ldots$ & 3.83 & 3.78 & 6 \\
\hline $\int 20 \overline{2}$ & $\ldots \ldots \ldots$ & & & \\
\hline$\{014$ & $\ldots \ldots \ldots$ & 3.75 & 3.75 & 9 \\
\hline$\left\{\begin{array}{l}220 \\
024\end{array}\right.$ & $\begin{array}{l}\ldots \ldots \ldots \\
\ldots \ldots \ldots \ldots\end{array}$ & $3.084 \mathrm{~b}$ & $\left\{\begin{array}{l}3.092 \\
3.078\end{array}\right.$ & 90 \\
\hline $\int 12 \overline{4}$ & $\ldots \ldots \ldots$ & & $\int 2.913$ & \\
\hline$\{130$ & $\ldots \ldots \ldots \ldots$ & 2.911 & $\left\{\begin{array}{l}2.909\end{array}\right.$ & 9 \\
\hline $30 \overline{2}$ & $\ldots \ldots \ldots$ & 2.647 & 2.646 & 9 \\
\hline$\{230$ & $\ldots \ldots \ldots$ & & $\int 2.484$ & \\
\hline$\{034$ & $\ldots \ldots \ldots$ & 2.481 & $\{2.476$ & 13 \\
\hline $23 \overline{2}$ & $\ldots \ldots \ldots$ & 2.395 & 2.395 & 7 \\
\hline$\{026$ & $\ldots \ldots \ldots$ & 2.357 & $\{2.357$ & \\
\hline$\{134$ & $\ldots \ldots \ldots$ & 2.357 & $\{2.355$ & 15 \\
\hline 313 & $\ldots \ldots \ldots$ & 2.341 & 2.341 & 11 \\
\hline 一 & $\ldots \ldots \ldots$ & 2.016 & - & 6 \\
\hline - & $\ldots \ldots \ldots$ & 1.943 & - & 7 \\
\hline 一 & $\ldots \ldots \ldots$ & 1.872 & - & 7 \\
\hline - & $\ldots \ldots \ldots$ & 1.543 & - & 5 \\
\hline - & $\ldots \ldots \ldots$ & 1.455 & - & 9 \\
\hline
\end{tabular}

$\mathrm{b}=$ broad.

The X-ray powder pattern of mpororoite is reproduced in Table 1 (Philips Norelco, filtered copper radiation, internal quartz standard). The indexing was made in a manner similar to that used for indexing the powder pattern of anthoinite (Sahama et. al., 1970). No anthoinite contamination could be detected in mpororoite. The mineral is most probably monoclinic or nearly so. The unit cell parameters refined from the powder pattern are:

$$
\begin{aligned}
& a_{0}=8.27 \pm 0.01 \AA \\
& b_{0}=9.32 \pm 0.01 \\
& c_{0}=16.40 \pm 0.02 \\
& \beta=92^{\circ} 29^{\prime} \pm 15^{\prime} \\
& V=1263 \AA^{3}
\end{aligned}
$$

When ignited to decompose the mineral, anthoinite and mpororoite give identical X-ray powder patterns. 
TABLE 2.

Chemical composition of mpororoite.

\begin{tabular}{|c|c|c|c|c|}
\hline & $\begin{array}{c}\text { Original } \\
\text { analysis } \\
\%\end{array}$ & $\begin{array}{l}\text { Free from } \\
\text { admixed } \\
\text { scheelite }\end{array}$ & Atomic & proportions \\
\hline $\mathrm{WO}_{3} \ldots$ & 66.90 & 66.69 & W & 1.00 \\
\hline $\mathrm{Al}_{2} \mathrm{O}_{3} \ldots \ldots$ & 8.22 & 8.33 & $\mathrm{Al}$ & $0.57]_{1}$ \\
\hline $\mathrm{Fe}_{2} \mathrm{O}_{3} \ldots \ldots$ & 9.78 & 9.91 & $\mathrm{Fe}$ & $0.43\}^{1.00}$ \\
\hline $\mathrm{CaO} \ldots \ldots$ & 0.27 & - & $\mathrm{O}$ & $4.50^{\prime}$ \\
\hline $\mathrm{H}_{2} \mathrm{O}+\ldots \ldots$ & 7.97 & 8.08 & $\mathrm{H}_{2} \mathrm{O}+$ & $1 . 5 6 \longdiv { 2 . 9 1 }$ \\
\hline $\mathrm{H}_{2} \mathrm{O}-\ldots$. & 6.89 & 6.98 & $\mathrm{H}_{2} \mathrm{O}-$ & $1.35\}$ \\
\hline Total & 100.03 & 99.99 & & \\
\hline
\end{tabular}

Sufficient material for a wet chemical analysis could be obtained by careful hand picking. The result of the analysis made by one of us (O.v.K.) is summarized in Table 2 . The material contained a small amount of admixed scheelite. The table also gives the composition of mpororoite corrected for this scheelite contamination and, in addition, indicates the atomic proportions based on $\mathrm{W}=1.00$.

Compared with the ideal anthoinite formula, $\mathrm{Al}_{2} \mathrm{O}_{3} \cdot 2 \mathrm{WO}_{3} \cdot 3 \mathrm{H}_{2} \mathrm{O}$, the water content of mpororoite is almost twice as high. The atomic proportions listed in Table 2 yield for the mineral the actual formula

$0.57 \mathrm{Al}_{2} \mathrm{O}_{3} \cdot 0.43 \mathrm{Fe}_{2} \mathrm{O}_{3} \cdot 2.00 \mathrm{WO}_{3} \cdot 5.82 \mathrm{H}_{2} \mathrm{O}$ or simplified

$$
(\mathrm{Al}, \mathrm{Fe})_{2} \mathrm{O}_{3} \cdot 2 \mathrm{WO}_{3} \cdot 6 \mathrm{H}_{2} \mathrm{O}
$$

This simplified formula makes no distinction between the $\mathrm{H}_{2} \mathrm{O}+$ and $\mathrm{H}_{2} \mathrm{O}$ - of Table 2 .

The material available did not allow a reliable pycnometric density determination. Assuming $Z=5$ for the simplified formula of mpororoite which corresponds to that of anthoinite, the density of the mineral is calculated to $D=4.59$. Because of the higher water content of mpororoite, this value is expectedly lower than that found for anthoinite $(D=5.06)$. The densities of the two minerals mentioned result in approximately equal densities of the oxygen packing in the structure.

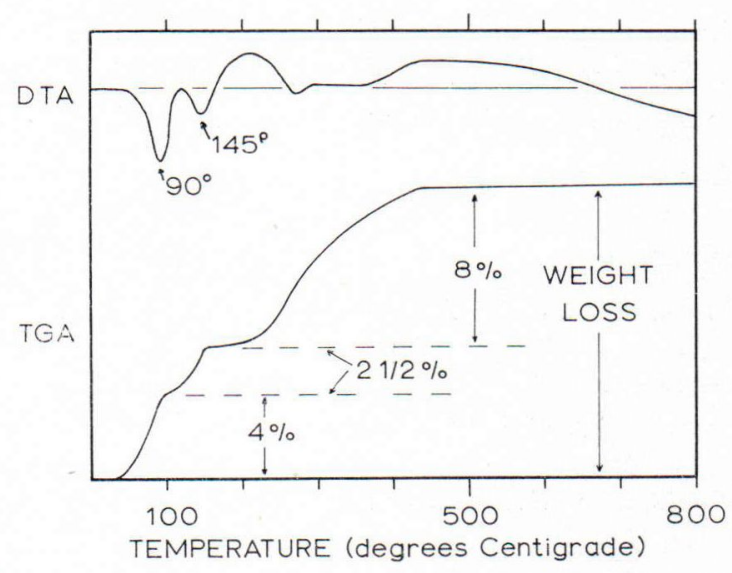

FIG. 1. Result of a combined DTA (differential thermal analysis) and TGA (thermogravimetric analysis) of mpororoite. Running speed $10^{\circ} \mathrm{C} / \mathrm{min}$.

According to the data given, the unit cell of mpororoite contains ideally $30 \mathrm{H}_{2} \mathrm{O}$. The role of this water remains to be studied. Therefore, a combined DTA and TGA run was made using ca. $30 \mathrm{mg}$ of the mineral (Fig. 1). The material obtained was slightly contaminated by ferberite and scheelite. Accordingly, only approximate values for the weight losses are given in the figure. Both the DTA and the TGA curves show marked differences from those of anthoinite, a fact which further justifies considering mpororoite as a distinct species. The DTA curve displays two sharp endothermic peaks at ca. $90^{\circ} \mathrm{C}$ and ca. $145^{\circ} \mathrm{C}$, respectively. Both these peaks correspond to points of sudden change in the TGA curve. It is concluded that the expulsion of water below $145^{\circ} \mathrm{C}$ occurs in two steps. The total amount of water expelled in these two steps corresponds roughly to the amount of $\mathrm{H}_{2} \mathrm{O}$ - indicated in Table 2 . It could be assumed that the $4 \% \mathrm{H}_{2} \mathrm{O}$ expelled below $90^{\circ} \mathrm{C}$ would represent secondary moisture. However, since anthoinite does not contain secondary moisture, it seems more likely that also the water expelled below $90^{\circ} \mathrm{C}$ belongs to the structure of the mineral. Above $145^{\circ} \mathrm{C}$, a further amount of ca. $8 \% \mathrm{H}_{2} \mathrm{O}$ is expelled corresponding roughly to 
the amount of $\mathrm{H}_{2} \mathrm{O}+$ given in Table 2. At a is contained as water molecules in the structure. temperature of ca. $420^{\circ} \mathrm{C}$ the dehydration is Whether $\mathrm{H}_{2} \mathrm{O}+$ is present as $\mathrm{H}_{2} \mathrm{O}$ or $\mathrm{OH}$ can completed. It is likely that the amount of $\mathrm{H}_{2} \mathrm{O}-$ not be decided.

\section{REFERENCES}

Combe, A. D. (1939) Annual Report of the Geological Survey Department, Entebbe.

Roe, F. W. (1943) Annual Report of the Geological Survey Department, Entebbe.

Manuscript received, December 15, 1971.
Sahama, Th. G., v. Knorring, Oleg, and Lehtinen' Martir (1970) New data for anthoinite. Bull. Geol. Soc. Finland, vol. 42, p. 95. 